\title{
POLAND IN THE EUROPEAN UNION. TEN YEARS OF MEMBERSHIP
}

\author{
Katarzyna Kolodziejczyk ${ }^{2}$ \\ University of Warsaw
}

\begin{abstract}
:
Twelve years have passed since the Polish entry into the European Union. For Poland the date of 1 May 2004 is the culmination of a transformation process launched at the end of the Cold War in 1989. One of the priorities of Polish foreign policy, the expansion of the political, economic and cultural relations with Western Europe and the United States has been met. This approach has been described as 'the return to Europe'. Membership in the European Union changed the Polish economy and the new politics opened up new opportunities for businesses and citizens. The aim of the article is to analyze the balance of the Polish membership in the European Union in the economic, financial, political and social dimensions.
\end{abstract}

Abstract: Poland, European Union, economic adjustments, exports and imports, financial flows, Polish presidency of the EU, Eastern Partnership, economic and social benefits.

\section{Resumen:}

Doce años han pasado desde la entrada de Polonia en la Unión Europea. Para Polonia, la fecha del 1 de mayo de 2004 supone la culminación de un proceso de transformación impulsado al final de la guerra fría en 1989. Una de las prioridades de la política exterior de Polonia que era la ampliación de las relaciones políticas, económicas y culturales con Europa Occidental y los Estados Unidos se ha llevado a cabo. Esta orientación ha sido descrita como "la vuelta a Europa". La pertenecía a la Unión Europea cambió la economía de Polonia y la nueva política abrió nuevas oportunidades para las empresas y los ciudadanos. El objetivo de este artículo es analizar las ventajas e inconvenientes de la pertenecía de Polonia a la Unión Europea en sus aspectos económicos, financieros, políticos y sociales.

Palabras clave: Polonia, Unión Europea, ajustes económicos, exportaciones e importaciones, flujos financieros, Presidencia polaca de la UE, Asociación Oriental, beneficios económicos y sociales.

Copyright (C) UNISCI, 2016.

Las opiniones expresadas en estos artículos son propias de sus autores, y no reflejan necesariamente la opinión de UNISCI. The views expressed in these articles are those of the authors, and do not necessarily reflect the views of UNISCI.

\footnotetext{
${ }^{2}$ Katarzyna Kolodziejczy is Associate Professor in social sciences, specialisation in political science. Staff member at the Institute of International Relations of the University of Warsaw.

E-mail: katarzyna.kolodziejczyk@poczta.onet.pl.

http://dx.doi.org/10.5209/rev_RUNI.2016.n40.51803
} 


\section{Introduction}

On 1 May 2014, Poland became a member of the European Union (EU), concluding the long process of striving to join this organisation. These efforts had been initiated by the international transformations of the 'Autumn of Nations' that resulted in an essential redefinition of Polish foreign policy, manifested in a purely pro-Western orientation and striving towards integration with Western European institutions. Formed by Tadeusz Mazowiecki in September 1989, the first non-Communist government set expanding political, economic and cultural relations with Western Europe and the United States as one of the priorities for Polish foreign policy. This approach was referred to as 'the return to Europe'. 3

Poland established diplomatic relations with the European Economic Community (EEC) in September 1988, and in the following year, on 19 September, it signed the first agreement with the EEC on trade and economic partnership. This agreement was important for the country's systemic transformation and the crumbling trade exchange within the Council for Mutual Economic Assistance (CMEA). Even though the conclusion of the association agreement between Poland and the European Community (EC) on 16 December 1991 did not provide Poland with any guarantee of future membership, it constituted the foundation for the further development of relations with the EC because it established an institutional and legal framework for long-term economic, political, social, and cultural cooperation.

The Polish application for membership to the European Union was launched on 8 April 1994. Having obtained a positive assessment from the European Commission, Poland was invited to the accession negotiations at the European Council meeting held in Luxembourg on 12-13 December 1997. The negotiations were concluded on 13 December 2002, and the Accession Treaty was signed on 13 April 2003. Once the ratification procedure was completed, Poland joined the EU on 1 May 2004 with nine other countries.

More than a decade has passed since then, and Poles quickly got accustomed to EU membership. Polish enterprises have entered into competition with companies from other countries in the single market, employees from Poland seek employment in other EU Member States, students benefit from EU scholarships, and common ordinary Poles cross borders as fully-fledged members of the Schengen area. The fears of losing sovereignty, of Polish land being purchased away by foreigners or of a demise of Polish agriculture have not realised. Instead, after slightly more than a decade, Poland made a significant leap forward and is now the leader of economic growth in the EU. The symbolical crowning achievement so far was the appointment of Donald Tusk to the office of President of the European Council in the tenth year after accession.

Of course, the outcome of Poland's membership in the EU includes some costs, but overall they have become beneficial for Poland because the adjustments to EU standards have supported the country's modernisation. The aim of this article is to analyse the effects of Poland's membership in the EU and to assess the costs and losses it has entailed. The underlying assumption, however, is that the decision to try and obtain EU membership was the best possible decision in terms of the Polish raison d'état. For the purpose of the analysis, the article has been divided into three parts. The first part concerns issues connected with the economic and financial dimension of Poland's membership in the EU, followed by an assessment of political gains and losses resulting from membership. The main reason for this design is that the EU has an exceptionally well-developed policy concerning a broadly defined economic integration, in contrast to the Common Foreign and Security Policy

\footnotetext{
${ }^{3}$ Mazowiecki, Tadeusz: "Powrót do Europy. Przemówienie na forum Rady Europy w Strasburgu" (A Return to Europe. A Speech Held in the Council of Europe in Strasburg), Znak, No. 416, Kraków (January 1990), pp. 3-9.
} 
(CFSP). The third analysed area is social issues, a basic element in any comprehensive evaluation of Poland's membership.

\section{Economic and Financial Aspects of Poland's Membership in the EU}

Poland began its relations with the EU as a post-communist and backward country taking its first steps on the path of systemic transformation from a central planned economy to market economy. The accession to the EU, 15 years after the transformation process had been launched, provided some hope for faster economic growth, but, at the same time, gave rise to anxiety and concerns for the competition from companies in other EU Member States. Economists expected that benefits and tangible economic results appear after a relatively long period of time (around 20 to 25 years after accession). However, within a single decade, Poland has become the European leader in economic growth and during its EU membership has experienced always a positive economic growth.

Table 1. Percentage Changes of Polish GDP Year over Year

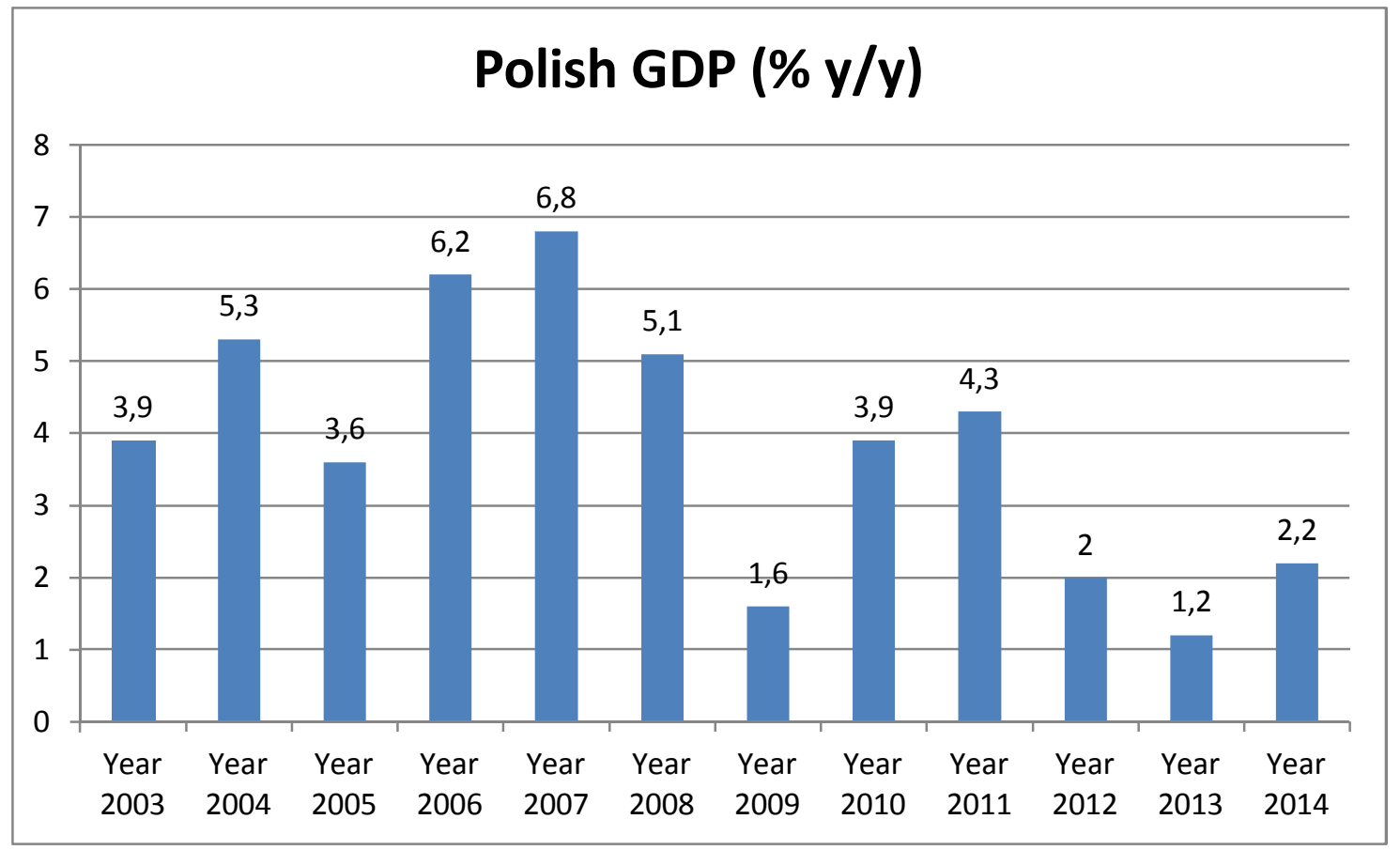

Source: Data from www.euro-dane.com

In terms of Gross Domestic Product (GDP), which is the most popular measure of the overall size of the economy, with the value of EUR 413 billion, Poland holds the eighth place in the EU in terms of nominal GDP, after Germany, France, the United Kingdom, Italy, Spain, the Netherlands, and Sweden (data available for 2014). Compared to the first five greater EU economies, the gap is immense and virtually impossible to overcome; for example, in 2014, Germany's GDP in current prices was EUR 2,904 billion (see Table 2). In terms of GDP at purchasing power parity per capita, an indicator used to assess the living standards, with the value of EUR 10,700, Poland holds only the $24^{\text {th }}$ place, followed by Croatia, Hungary, Bulgaria, and Romania. This figure is below the EU average, which in 2014 was EUR 27,300 
(see Table 2). Nevertheless, the success of the Polish economy is huge because, after the country's accession to the EU, Polish GDP increased by almost a half (48.7\%). GDP at purchasing power parity per capita in 2003 was 48.8 per cent of the EU average, and now it is 66.9 per cent, ${ }^{4}$ which means that economic growth has sped up the process of eliminating development-related disparities.

Table 2. GDP in Current Prices in 2003-04 and 2012-14

\begin{tabular}{|c|c|c|c|c|c|c|c|c|c|c|c|c|}
\hline & \multicolumn{8}{|c|}{ GDP } & \multicolumn{4}{|c|}{ GDP per capita } \\
\hline & \multicolumn{5}{|c|}{ (billion EUR) } & \multicolumn{3}{|c|}{ (billion PPS) } & \multicolumn{3}{|c|}{ (PPS, EU-28 $=100$ ) } & \multirow{2}{*}{$\begin{array}{l}\text { (EUR) } \\
2014\end{array}$} \\
\hline & 2003 & 2004 & 2012 & 2013 & 2014 & 2003 & $2012(1)$ & 2013 & 2003 & $2012($ (') & 2013 & \\
\hline EU-28 & 10490 & 11016 & 13426 & 13520 & 13921 & 10490 & 13426 & 13520 & 100 & 100 & 100 & 27300 \\
\hline Euro area (EA-19) & 7825 & 8157 & 9846 & 9931 & 10111 & 7599 & 9607 & 9621 & 109 & 107 & 107 & 29800 \\
\hline Belgium & 282 & 298 & 388 & 395 & 402 & 271 & 350 & 351 & 123 & 120 & 119 & 36000 \\
\hline Bulgaria & 19 & 21 & 41 & 41 & 42 & 55 & 87 & 86 & 33 & 45 & 45 & 5800 \\
\hline Czech Republic & 88 & 96 & 161 & 157 & 155 & 169 & 229 & 230 & 77 & 82 & 82 & 14700 \\
\hline Denmark & 193 & 202 & 251 & 253 & 257 & 142 & 185 & 186 & 124 & 125 & 124 & 45600 \\
\hline Germany & 2217 & 2268 & 2750 & 2809 & 2904 & 2040 & 2661 & 2673 & 116 & 123 & 122 & 35200 \\
\hline Estonia & 9 & 10 & 18 & 19 & 20 & 15 & 25 & 26 & 52 & 71 & 73 & 14800 \\
\hline Ireland & 145 & 155 & 173 & 175 & 185 & 121 & 158 & 159 & 141 & 130 & 130 & 40200 \\
\hline Greece & 179 & 193 & 194 & 182 & 179 & 219 & 217 & 214 & 93 & 74 & 73 & 16300 \\
\hline Spain & 803 & 861 & 1055 & 1049 & 1058 & 901 & 1166 & 1165 & 100 & 94 & 94 & 22800 \\
\hline France & 1637 & 1711 & 2091 & 2114 & 2142 & 1474 & 1863 & 1869 & 111 & 107 & 107 & 32400 \\
\hline Croatia & 31 & 33 & 44 & 44 & 43 & 51 & 69 & 69 & 56 & 61 & 61 & 10200 \\
\hline Italy & 1391 & 1449 & 1615 & 1609 & 1616 & 1376 & 1608 & 1595 & 112 & 101 & 99 & 26600 \\
\hline Cyprus & 13 & 14 & 19 & 18 & 18 & 14 & 21 & 20 & 94 & 93 & 89 & 20500 \\
\hline Latvia & 10 & 12 & 22 & 23 & 24 & 22 & 32 & 34 & 45 & 60 & 64 & 12100 \\
\hline Lithuania & : & 18 & 33 & 35 & 36 & & 55 & 57 & 48 & 69 & 73 & 12400 \\
\hline Luxembourg & 26 & 28 & 44 & 45 & : & 23 & 37 & 37 & 240 & 264 & 257 & \\
\hline Hungary & 75 & 83 & 99 & 101 & 103 & 133 & 170 & 174 & 62 & 65 & 66 & 10500 \\
\hline Malta & 5 & 5 & 7 & 8 & 8 & 7 & 9 & 10 & 82 & 84 & 86 & 18600 \\
\hline Netherlands & 506 & 520 & 641 & 643 & 655 & 461 & 587 & 586 & 133 & 132 & 131 & 38900 \\
\hline Austria & 231 & 242 & 317 & 323 & 329 & 220 & 288 & 289 & 127 & 129 & 128 & 38500 \\
\hline Poland & 192 & 205 & 386 & 396 & 413 & 388 & 670 & 689 & 48 & 66 & 67 & 10700 \\
\hline Portugal & 146 & 152 & 168 & 169 & 173 & 175 & 211 & 217 & 78 & 76 & 79 & 16600 \\
\hline Romania & 53 & 61 & 134 & 144 & 150 & 142 & 281 & 289 & 31 & 53 & 55 & 7500 \\
\hline Slovenia & 26 & 28 & 36 & 36 & 37 & 35 & 44 & 45 & 83 & 82 & 82 & 18100 \\
\hline Slovakia & 30 & 35 & 72 & 74 & 75 & 63 & 106 & 108 & 55 & 74 & 75 & 13900 \\
\hline Finland & 152 & 158 & 200 & 202 & 204 & 127 & 166 & 164 & 114 & 115 & 113 & 37400 \\
\hline Sweden & 293 & 307 & 423 & 436 & 429 & 242 & 318 & 324 & 127 & 126 & 127 & 44300 \\
\hline United Kingdom & 1720 & 1850 & 2041 & 2017 & 2222 & 1568 & 1810 & 1852 & 123 & 107 & 109 & 34400 \\
\hline Iceland & 10 & 11 & 11 & 12 & 13 & 8 & 10 & 10 & 126 & 116 & 119 & 39500 \\
\hline Norway & 202 & 213 & 397 & 393 & 377 & 150 & 253 & 252 & 154 & 190 & 186 & 73400 \\
\hline Switzerland & 312 & 317 & 518 & 516 & : & 225 & 340 & 348 & 136 & 162 & 163 & 10 \\
\hline Montenegro & : & : & : & : & $:$ & : & : & : & : & 39 & 40 & 7 \\
\hline FYR of Macedonia & 4 & 5 & 8 & 8 & & 11 & 19 & 20 & 27 & 34 & 36 & : \\
\hline Albania & : & : & : & & $:$ & $:$ & 21 & : & : & 28 & 28 & : \\
\hline Serbia & 19 & 20 & 32 & 34 & 33 & : & 70 & 70 &  & 37 & 37 & : \\
\hline Turkey & : & : & : & : & & & & : & 35 & 52 & 53 & : \\
\hline Bosnia and Herzegovina & : & : & : & $\therefore$ & $:$ & $:$ & : & : & : & 28 & 29 & 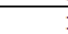 \\
\hline Japan & & : & $\therefore$ & : & 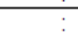 & : & 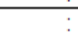 & : & 111 & 102 & 103 & \\
\hline United States & 10176 & 9868 & 12580 & 12626 & 13112 & 9704 & 12289 & 12662 & 157 & 148 & 150 & 41100 \\
\hline
\end{tabular}

(') Break in series.

Source: Eurostat (online data codes: nama_10_gdp, nama_10_pc and tec00114)

Source: Eurostat: Statistics Explained, at www.ec.europa.eu/eurostat

The source of the Polish economic success lies in the growth of the export sector, inflow of foreign direct investments, structural funds, as well as strong domestic demand and improved productivity. Polish exports, however, have become the real driving force behind economic development, which is consistent with the international approach to the notion of development, where trade plays the key role. Starting with 1989, Poland successfully

\footnotetext{
4 Ministry of Foreign Affairs (2014): Poland's 10 years in European Union. Report, Warsaw, p. 66, at www.msz.gov.pl. More on the Polish economy: Piątkowski, Marcin: "Poland's New Golden Age. Shifting from Europe's Periphery to Its Center", Policy Research Working Papers No. 6639, The World Bank (October 2013).
} 
implemented the task of opening its economy to the world and perceived the EU countries as its natural trade partners. For Polish businesses, Poland's accession to the EU meant that they would be subject to the free movement of goods. Although the Association Agreement that paved the way to the accession, established a free trade area between Poland and the European Community, it excluded food and agricultural products, and these were the goods that experienced the most significant increase in the exports to the EU. In 2004-2014 Polish exports to the EU almost tripled, increasing from EUR 48.4 billion to 125.2 billion, a 4.3 per cent of total intra-EU exports (in 2004, it was 2.3 per cent) and put Poland in the eighth place among the leading exporters in intra-EU trade. For Polish exporters, the EU market is the main sales market and accounts for approximately 75 per cent of total Polish exports. Five years after accession to the EU, Poland recorded a trade surplus in trade exchange with other EU countries for the first time. It was a considerable success, given the fact that it had been experiencing a trade deficit since the conclusion of the Association Agreement. In 2004, the trade deficit with the EU was EUR 5.85 billion, but ten years later, the trade balance shifted to a surplus of EUR 11.07 billion. ${ }^{5}$ Poland's exports to the EU market include electro-machinery products $(37 \%)$, products of the chemical industry $(14.2 \%)$, food and agricultural products $(13.8 \%)$, and metallurgical products $(11.4 \%){ }^{6}$ Among these groups of commodities, as mentioned above, it was the food and agricultural products that have achieved a spectacular success. Since Poland became a member of the EU, the volume of exports of these goods to the EU increased more than fivefold, and the value rose from 16 billion euro to 22,7 billion euro. Poland became the leader in exports of rye, frozen fruit (strawberries), poultry, eggs, juice, fruit preserves, and tinned vegetables. Additionally, on 1 May 2004, Poland became one of the EU's leaders in exports of household appliances, furniture, products of the automotive industry, yachts and boats, TV sets and LCD displays and cosmetics. ${ }^{7}$

However, as regards the opportunity to enter the markets of non-EU countries provided by the EU's Common Commercial Policy and the EU agreements with third countries, Poland used this last one to a much lesser extent. Poland's exports in the EU's external trade increased from EUR 11.8 billion in 2004 to EUR 37.7 billion in 2014. However at present, exports to non-EU countries comprise around 25 per cent of total Polish exports. In the period under analysis, Poland's trade deficit with third countries was increasing as well, growing from EUR 5.92 to 13.51 billion. ${ }^{8}$ These results, nevertheless, leave Polish exporters with opportunities to seek greater benefits in foreign markets; even more so as the EU presently has negotiated or is in the process of negotiation of the highest number of trade agreements in the world, ensuring mutual access to markets (for example, it has signed agreements with Mexico, Chile, Singapore, South Korea, the ACP countries, and Canada, and is currently negotiating one with the United States).

Contrary to the predictions of the opponents of Poland's accession to the EU, Poland's participation in the common market has not led to the demise of Polish entrepreneurship. Instead, Polish companies have skilfully taken advantage of the opportunities offered by the common market and quickly adjusted to the EU rules on technical, sanitary and phytosanitary standards. Ten years after the accession, one in three (32\%) of Polish small, medium and large enterprises engages in export activities. Most of them are active in industry, trade, transport, professional and service activity, and construction. ${ }^{9}$ Furthermore, the development of Polish

\footnotetext{
${ }^{5}$ Eurostat: Intra EU-27 trade, by Member States, total product, data of 2.03.2015, at www.ec.europa.eu/eurostat

${ }^{6}$ Polska 2014. Raport o stanie handlu zagranicznego (Poland 2014. A Report on the State of Foreign Trade), Ministry of Economy, Warszawa 2014, p. 43, at www.mg.gov.pl

${ }^{7}$ Ministry of Foreign Affairs (2014): Poland's 10 years in ...op. cit., pp. 84-85.

${ }^{8}$ Eurostat: Extra EU-27 trade, by Member States, total product, data of 02.03.2015, at www.ec.europaa.eu/eurostat

${ }^{9}$ Ministry of Foreign Affairs (2014): Poland's 10 years in ...op. cit., pp. 99-100.
} 
business had a positive effect on the evolution of the services sector both in Poland and in the EU market. Many Polish companies provide services, which, in turn, contributed to structural changes of the Polish economy, leading to a situation typical of the developed market economies: increased significance of the service sector in employment and GDP generation at the expense of agriculture. At present, 57.6 per cent of workers in Poland are employed in the services sector (while $30.8 \%$ are employed in in industry and $11 \%$ in agriculture), which generates 64 per cent of the Polish GDP. ${ }^{10}$ Analysing statistical data, we notice, however, that Poland has taken advantage of the opportunities brought by the free movement of services that has been in force in the EU since 1 January 1993 only to a limited extent (compared to the trade in goods). The value of Polish exports in intra-EU trade is EUR 22.5 billion, which is only 2.7 per cent of total internal EU exchange; the value of imports is EUR 19.7 billion, that is 2.6 per cent. Poland's results in exports of services to the EU market is unfavourable compared to those of smaller economies (e.g.: Belgium 6.6\%, Ireland 6.3\%, Austria 37\%) and absolutely incomparable to the results of the large economies (e.g.: Germany $112 \%$, the UK 79.6\%, Spain 75.7\%). ${ }^{11}$ Moreover, Poland has not yet taken advantage of the opportunities provided by the EU's trade agreements with third countries, to which Poland has been a party since its accession to the Union. These agreements remove trade barriers not only in the movement of goods but also in services, pursuant to Article V of the General Agreement on Trade in Services (GATS). Poland's share in the EU's overall international exchange of services is negligible. Its share in EU exports of services to third countries amounts to a mere EUR 7.7 billion, which constitutes only a 1.1 per cent share in total exports of services in the EU's exchange with third countries. In imports, the amount is EUR 5.3 billion, which is 1.0 per cent of total imports. ${ }^{12}$ These figures should give Polish companies wider opportunities to search for markets, especially given the fact that an agreement with Canada, among others, and EPAs with the countries of Sub-Saharan Africa (including South Africa) are expected to be ratified soon and perhaps trade negotiations with the United States will be completed as well.

Poland's accession to the EU undoubtedly attracted foreign direct investments (FDI). This is because EU membership increases the attractiveness of countries, makes them more credible to investors and guarantees observance of EU law. All this, combined with Poland's good economic results and political stability, has attracted foreign capital in substantial quantities. The figure is higher than those of other countries of Central and Eastern Europe.

Table 3. Net FDI Inflow to Poland between 2003 and 2013

\begin{tabular}{|c|c|c|c|}
\hline Year & $\begin{array}{c}\text { Value (EUR } \\
\text { billion) }\end{array}$ & Year & Value (EUR billion) \\
\hline 2003 & 4.08 & 2009 & 9.34 \\
\hline 2004 & 10.23 & 2010 & 10.50 \\
\hline
\end{tabular}

\footnotetext{
${ }^{10}$ Data from: www.rynekpracy.org.pl. In 1990, the agricultural sector employed 22\% workers, and in 1995 the service sector employed $46 \%$ workers. This share is constantly growing.

${ }^{11}$ Eurostat: Contribution to intra EU-28 trade in services, 2013, data of 25.08.2014, at www.ec.europa.eu/eurostat

12 Eurostat: Contribution to extra EU-28 trade in services, 2013, data of 16.05.2014, at www.ec.europa.eu/eurostat
} 


\begin{tabular}{|c|c|c|c|}
\hline 2005 & 8.33 & 2011 & 14.89 \\
\hline 2006 & 15.74 & 2012 & 4.76 \\
\hline 2007 & 17.24 & 2013 & 2.20 \\
\hline 2008 & 10.12 & 2014 & no data \\
\hline
\end{tabular}

Source: Response of the Undersecretary of State in the Ministry of Economy to interpellation No. 21594 on FDI inflow to Poland, www.orka2.sejm.gov.pl

As shown in Table 3, the difference in FDI inflow between 2003 and 2004, when Poland became a member of the EU, is significant. Top FDI inflow was recorded in 2006 and 2007 as well as 2011, when they reached EUR 15.7 billion, 17.2 billion and 14.8 billion, respectively. The worse results in 2012 and 2013 were caused primarily by the economic crisis in the euro area, as its members are among the chief investors in Poland $(90 \%$ of total commitments, of which Germany accounts for $17 \%$, the Netherlands for $16 \%$, France for $12 \%$, and Luxembourg for 10\%). Furthermore, capital in transit was withdrawn, special purpose entities were closed down and equity interest of foreign investors was withdrawn as well. ${ }^{13}$ Still, in 2013 the aggregated value of FDI in Poland was EUR 160 billion, which means an almost fourfold growth compared to EUR 44 billion in 2004. Almost 32 per cent of commitments under FDI were the result of investments in industrial processing (manufacturing of metal products, food products, beverages, tobacco products, vehicles), 24 per cent in financial and insurance activity, and 14 per cent in retail and wholesale, repair of cars and motorcycles. ${ }^{14}$ Without going into details of the impact of FDI on the Polish economy, we can generally state that they contributed to an increase in the production efficiency, to the general modernisation of the Polish economy and to an increase in exports since the share of entities with foreign capital in the value of Polish exports is approximately 60 per cent. ${ }^{15}$

When conducting an analysis of the economic and financial gains and losses related to Poland's membership in the EU, one cannot omit financial flows from the EU. In the 134 months of Poland's membership in the EU (as of 30 June 2015), Poland received a total amount of EUR 119.8 billion from the EU budget. In the same period, Poland contributed a total of EUR 37.6 billion to the EU budget and returned EUR 143 million of unspent funds. The balance is a surplus of EUR 82 billion. ${ }^{16}$ Poland received from the EU Cohesion Policy, EUR 76.4 billion, from agricultural policy, 39 billion, and 4.4 billion from other transfers. ${ }^{17}$

\footnotetext{
${ }^{13}$ National Bank of Poland (March 2015): Polskie i zagraniczne inwestycje bezpośrednie w 2013 r. (Polish and Foreign Direct Investments in 2013), p. 12.

${ }^{14}$ GUS (April 2014): Poland in the European Union 2004-2014, p. 58, at: www.stat.gov.pl

${ }_{15}^{15}$ Ministry of Foreign Affairs (2014): Poland's 10 years in ...op. cit., p. 101.

${ }^{16}$ Ministry of Finance: Transfery finansowe pomiędzy Polska a UE wedtug stanu na dzień 30 czerwca 2015 r. (Financial Transfers between Poland and the EU as of 30 June 2015), www.mf.gov.pl

17 The 'other transfers' mean movements of capital related to EU programmes, including: Socrates, Erasmus, Youth, Leonardo da Vinci. Statistical data based on: Ministry of Finance: Zestawienie transferów finansowych budzet UE-Polska (Financial Transfers between the EU Budget and Poland), at www.mf.gov.pl.
} 
Table 4. Funds Received from the European Union (in EUR) in the First 10 years of Membership

\begin{tabular}{|l|c|}
\hline & $1.05 .2004-31.12 .2014$ \\
\hline Funds from the EU budget & $\mathbf{1 0 9 . 6}$ billion \\
\hline Polish contribution to the EU budget & 35 billion \\
\hline Funds returned to the EU & 143 million \\
\hline BALANCE & 74.3 billion \\
\hline
\end{tabular}

Source: Own compilation on the basis of data published by the Ministry of Finance for 2004-2014, at: www.mf.gov.pl

Since Poland became a member of the European Union, the funds provided by the EU budget have been regularly increasing - from EUR 2.47 billion in 2004 to EUR 17.12 billion in 2014 - and have become an exceptionally important factor stimulating Poland's economic growth. Poland has become the major net beneficiary of EU funds among the new Member States and since 2011, among all the Member States. The funds allocated to Poland for 2014-2020 (approx. EUR 119.5 billion) will allow it to maintain this position. The increasing amount of funding from the EU budget is, however, explained by a very high degree of absorption, which exceeds the EU average $(60.8 \%)$ by 6 per cent and the average for Central and Eastern Europe $(58.4 \%)$ by 8.4 per cent. ${ }^{18}$ Poland skilfully took advantage of the opportunities provided by pre-accession programmes, quickly learning how to write applications, training administration staff and creating (in 2005) a separate ministry responsible for the use of funds provided by the EU (Ministry of Regional Development). ${ }^{19}$ More than 170000 projects have been executed under Cohesion Policy, which enabled the development of road infrastructure, environmental protection infrastructure as well as gas, electricity and energy infrastructure. Furthermore, support has been provided to enterprises, business environment institutions, universities and research and cultural centres, and the network of new e-services has been expanded. $^{20}$

EU funds have also been provided to farmers and fishermen under the Common Agricultural Policy and the Common Fisheries Policy. Farmers, a group that used to be the most sceptical of Poland's accession to the EU, are currently considered the greatest beneficiaries of the EU membership. Between May 2004 and the end of December 2014, Polish rural areas received EUR 39 billion, including 21.3 billion in direct subsidies and 15.6 billion for rural development. Thanks to EU funds and the policy of the Polish government, Polish agriculture has been thoroughly modernised. The real value of agricultural production increased by 50 per cent, and Polish farms generate production that according to global value (in current prices) places Polish farming on the $7^{\text {th }}$ place in the EU, following France, Germany, Italy, Spain, the UK, and the Netherlands. ${ }^{21}$ Poland has become an important

\footnotetext{
${ }^{18}$ Data from: Poland's 10 years in ...op. cit., p. 146.

${ }^{19}$ Presently the Ministry of Infrastructure and Development

${ }^{20}$ More on the projects at www.funduszeeuropejskie.gov.pl and in the report by the Ministry of Foreign Affairs: Poland's 10 years in European Union, op. cit., pp. 144-159.

${ }^{21}$ Poland is in the $1^{\text {st }}$ place in terms of production of apples, triticale and black current; $2^{\text {nd }}$ in terms of rye, champignons, potatoes and berries. $3^{\text {rd }}$ place in the production of rape, sugar beets, butter, poultry meat. Data according to the Ministry of Agriculture and Rural Development, at www.minrol.gov.pl
} 
exporter of food and agricultural products; the value of these exports has increased fivefold, from EUR 4 billion in 2004 to 21.3 billion in 2014. A particularly important element of rural areas transformation are the structural changes that took place after Poland joined the EU. Compared with data from 2002, there was a 25 per cent decrease in the number of the smallest farms ( $0-5$ ha of agricultural area) and a 34 per cent increase in the number of the largest farms (of 50 ha and more). The number of farms in the 20-50 ha group remained unchanged. Furthermore, between 2003 and 2013, the number of people employed in agriculture decreased by approximately 13.4 per cent. ${ }^{22}$ Additionally, since the accession, the income of farmers has increased threefold, but there is still a visible income gap between farmers and other professional groups. Finally, the level of satisfaction among inhabitants of rural areas is rising, as is their acceptance of the EU - from a mere 39 per cent in 2004 to 71 per cent in 2014. Similar changes have taken place in the fishing sector, which has undergone a thorough restructuring since Poland's accession to the EU and has experienced an expansion of harbour infrastructure and the modernisation of fish processing. Although the changes were often painful and despite protests of workers employed in the fishing sector and the introduction of fishing quotas, the value of production increased by 190 per cent, and in 2012 the overall number of available jobs in the fishing industry was 12 per cent higher than in 2003 . $^{23}$ To sum up, the transformations caused by different types of EU funds can be observed all over Poland, in small towns, large cities and villages alike, and they are a tangible proof of the positive changes resulting from Poland's membership in the EU.

\section{Political Aspects of Poland's Membership in the EU}

When Poland became a full-fledged member of the European Union, Polish authorities were given opportunities to influence the integration processes taking place within this organisation. Poland became a co-host of Europe rather than its supplicant. ${ }^{24}$ It received full rights allowing it to exert real influence for shaping the EU, its internal and external policy and the institutional system. The first years after accession (until November 2007) were not the most fortunate ones for Poland as regards the political dimension of the membership. When rightist groups rose to power in October 2005, Poland stubbornly defended the Nice voting system, without being supported by any other country or EU institution. By spreading slogans such as 'Nicea albo śmierć' ('Nice or death') or putting forward proposals of a 'square root model' for counting votes in the EU Council, Poland made a diplomatic mistake because the change of the double majority decision-making system had been a closed chapter ever since March 2004, when the then governing Centre-Left coalition had agreed to the content of the constitutional Treaty. Even though the departure from the Nice system is not beneficial to Poland, which could justify the position of the Polish rightist government, the fact that it remained obstinate and completely alone gave rise to considerable dislike for Poland in the EU institutions, the then President of the European Parliament Hans-Gert Pöterring and the German Chancellor Angela Merkel. ${ }^{25}$ A similar fate awaited the Polish initiative put forward by Prime Minister Kazimierz Marcinkiewicz in January 2006,

\footnotetext{
${ }^{22}$ Ministry of Agriculture and Rural Development (April 2014): Polski sektor rolno-żywnościowy i obszary wiejskie po 10 latach członkostwa w UE - przegląd najważiejszych zmian (Polish Food and Agriculture Sector and Rural Areas after 10 Years of EU Membership - An Overview of the Major Changes), at Www.minrol.gov.pl

${ }^{23}$ Data from: Poland's 10 years in...op. cit., p. 185.

${ }^{24}$ Office of the Committee for European Integration (2009): 5 years of Poland in European Union, Warszawa, p. 378.

${ }^{25}$ More to be found in: Kołodziejczyk Katarzyna (2010): "Poland's innovativeness and creativity in the European Union", in Bieleń, S. (ed.) (2010): Poland's Foreign Policy in the $21^{\text {st }}$ Century, Warszawa, pp. 145-155.
} 
concerning the establishment of the European Energy Security Treaty by the countries of the EU and NATO. The proposal was aimed at developing a mechanism that would ensure that in the event of threats to energy security in any EU, the other countries would have to come to its aid, excluding armed intervention. The core of the pact would be the 'one for all, all for one' principle. However, also in this case the Polish proposal was rejected - both in the EU and NATO. It can be debated whether the proposal was reasonable or not, taking into consideration that it was presented after the interruptions in the supply of gas from Russia to EU countries through the territory of Ukraine, at the turn of 2005 and 2006; surely its biggest flaw was the manner in which it was proposed, namely with no prior diplomatic consultation in the EU or NATO and alongside a Commission proposal on energy policy presented in a Green Paper in March 2006. Naturally, no country could accept the way it was done, all the more so as the proposal concerned a very sensitive political issues embedded in energy security and in the relations with Russia.

The poor political experience in the first years after accession was an excellent lesson, and Poland was able to learn from it. The coalition of the Civic Platform (PO) and the Polish People's Party (PSL) that governed Poland from November 2007 departed from the practice of the previous government and started creating or joining coalitions on various issues in the EU. The composition of these coalitions depended on the subject that was being negotiated. The 'alliances' of the so called 'friends of cohesion' during the negotiation of the multiannual financial frameworks 2007-2013 and 2014-2020 are an example of such a coalition. The group was composed of the countries that benefited the most from the EU's Cohesion Policy, that is the new Member States as well as Portugal, Greece and Spain (the latter also cooperated with the 'net contributors' group). Despite the large number of members and their diverging interests, Poland tried to use the group as an instrument of support for maintaining budgetary decisions as favourable as possible. This was particularly important during the negotiations on the EU's spending in 2014-2020, given the attempts of the net contributors to reduce it, also at the cost of Cohesion Policy; moreover, the negotiations were conducted in an atmosphere of economic crisis and growing problems in the euro area. At that time, Poland became the leader of this group. It organised the group's meetings and strived to keep Spain within it following the 2012 Spanish elections, which led to a change in the ruling power. Surely Poland's activity in this regard, supported by many other EU countries achieved several objectives: EU budget cuts relatively low compared to the initial proposals, the adoption of the multiannual financial framework without a delay that could threaten timely payments for the Member States, and a positive result in the financial negotiations for Poland itself. In the last case, apart from having the backing of other countries, Poland had very strong assets, given its economic growth, even under economic crisis, and its high spending of EU funds.

Another example of a successful coalition initiated by Poland, this time with Sweden, was the Eastern Partnership, launched on 7 May 2009. Next to the efforts to join NATO and the EU, the Eastern Policy was one of the key priorities of Polish foreign policy. Poland's interest and involvement in the events taking place in the East had been an integral part of Polish foreign policy since 1989 (e.g.: the Rose Revolution in Georgia of 2003-2004, the Orange Revolution in Ukraine of 2004-2005). At the same time, the goal behind Poland's activity in the EU was to make the other Member States interested in the matters concerning the eastern neighbourhood, similarly to France's policy towards the countries of the Mediterranean Basin or its former colonies. Poland strived to extend the EU's political and economic model to the post-Soviet countries and promoted deepened cooperation with them as well as gradual integration. Russia had a separate place in Polish eastern policy and a special status of 'strategic partner' in EU policy. Poland's efforts were focused, among others, 
on its eastern neighbours, although due to the situation in Belarus it was Ukraine and Moldavia the countries that came to the foreground, with Poland supporting their proEuropean ambitions and advocating association agreements with these countries. The second sphere of interest for Polish eastern policy included the countries of Transcaucasia and Central Asia. ${ }^{26}$ The Polish/Swedish initiative received broad support despite the fact that in May 2004 the EU implemented the concept of the European Neighbourhood Policy (ENP), covering the countries that the Eastern Partnership addressed later: Belarus, Moldova, Ukraine, Armenia, Azerbaijan, and Georgia. The reason was that the solution proposed by Poland and Sweden was very interesting; it was based on the assumption that the Eastern Partnership should be executed in accordance with the rules of the ENP but could expand to include the ENP's mechanisms and what it offered. The proposal included multilateral and bilateral cooperation - a step forward compared to the ENP, which excluded multilateral cooperation. The planned areas of common interest were: political and security issues, matters related to borders and the movement of people, economic and financial issues, as well as environmental and social issues. The key results of the Eastern Partnership are the association agreements concluded with Georgia, Moldova and Ukraine, but the ultimate assessment of the initiative cannot be very positive, given the situation in Ukraine. The EU's lack of interest in solving the conflict in Ukraine (except for the sanctions imposed on Russia) and its focus on its own economic problems (the Greek debt, illegal immigrants) have proven that, contrary to the Polish wishes, the main EU decision-making centres are not interested in the Eastern Policy.

The hallmark of Poland's membership in the EU in political terms so far is the Presidency of the Council of the European Union, which Poland held in the second half of 2011. Poland used this semester to consolidate its position in the Union as a country with good knowledge of the mechanics behind the EU and able to seek a compromise and common solutions in difficult issues. This was especially difficult at the time of disagreements emerging among the EU Member States with regard to the deepening crisis in the euro area as well as the obviously decreasing support for the idea of European integration and when the revolutions in Arab countries started. The main achievements of the Polish Presidency include the efficient adoption of the 2012 EU budget, despite economic problems and strong opposition from the UK; the conclusion of the accession treaty with Croatia; reacting and taking initiatives with regard to the euro area debt crisis (the 'six-pack'); and the conclusion of negotiations on the association agreement with Ukraine. The failures, in turn, include the lack of a final declaration after the Eastern Partnership summit and the absence of the French president Nicolas Sarkozy at that summit, which showed that France did not support the Polish initiative; the lack of progress regarding the admission of Romania and Bulgaria to the Schengen area due to the Dutch veto, and finally, the lack of arrangements concerning facilitation of shale gas extraction. Generally, however, the opinions about the Polish Presidency were very positive. Martin Schulz described it as 'one of the very best presidencies we have had', and the then President of the European Commission José Manuel Barroso praised it saying: 'Poland demonstrated extraordinary capacity [during] probably the most difficult period since the European integration started'. ${ }^{27}$

Poland also used the time of the Presidency in the Council to accentuate more strongly its position towards the EU and the processes taking place in it. It promoted the idea of unity

\footnotetext{
${ }^{26}$ Kowal, P. (2014): "Sztuka przekonywania. Polska a polityka wschodnia Unii Europejskiej w latach 20042014" (The Art of Persuasion. Poland and EU's Eastern Policy in 2004-2014), in Bezpieczeństwo Narodowe 2014/IV, p. 78.

27 "Poland sees praise for EU presidency in turbulent time", EUobserver, 14 December 2011, at www.euobserver.com.
} 
of the entire EU and the use of Union mechanisms rather than intergovernmental solutions as the latter make it easier for the EU's major actors to pursue their goals. In the opinion of German political scientists (Olaf Lang, Anna Quirin), the struggle for the EU's unity and preventing deeper divisions between the euro area and the other Member States is the key success of the Polish Presidency in the Council. ${ }^{28}$ Thanks to Poland's efforts, the negotiations on the reform of the euro area are open to non-euro-area countries, despite France's opposition. The Treaty on Stability, Coordination and Governance (TSCG) gives non-euroarea Member States the right to participate in negotiations on Title III (Fiscal Compact) and IV (Economic Policy Coordination and Convergence). Thanks to this treaty, a vast majority of EU Member States (except for the UK and the Czech Republic) will cooperate towards fiscal discipline, and non-euro-area countries will be able to participate in euro summits devoted to proper functioning of the Economic and Monetary Union, including the issue of stimulating competitiveness and employment as well as further stabilisation of public finance. Similarly, the first stage of supervision over the banking sector under the banking union comprising the euro area countries is open also to countries that have not joined the common currency area. Moreover, in line with Polish proposals, further comprehensive reform of the Economic and Monetary Union - concerning the banking, fiscal and economic union - will be incorporated into the institutional and legal framework of the EU. ${ }^{29}$ With this, it has been ensured that the new solutions would be open to countries that remain outside the euro area.

Poland is also an active participant in the Common Security and Defence Policy (CSDP), mainly through the civilian missions and military operations conducted within its framework. Currently (as in September 2015) Poland takes part in the missions in Moldova and Ukraine, Iraq, Georgia, Afghanistan, and Kosovo as well as in the largest EU operation in Bosnia and Herzegovina, which the EU took over from NATO in December 2004. Thanks to these activities Poland was able to consolidate its image of a reliable EU member who implements its obligations resulting from the process of European integration. Poland's confidence grew with every year of membership, translated into bold presentations of its own initiatives. A good example of this is the Polish initiative aimed at establishing a mission in Georgia as well as the so called Chobielin initiative, which was, however, never implemented and which advocated the establishment of command structures independent of NATO to be used in the execution of EU operations, the appointment of a special deputy for military issues to the High Representative of the Union for Foreign Affairs and Security Policy as well as the creation of special stabilisation forces. ${ }^{30}$ Since 2012, Poland has been engaged (alongside the countries of the Weimar Triangle, the Visegrad Group and the Baltic Countries) in activities for the strengthening of the CSDP, mainly through the development of a new European Security Strategy, the present one not having been modified since 2003. Correct definition of the threats to and problems for European security should translate into an increased sense of security in the EU.

The area that is essentially most problematic for Poland from both the political and the economic point of view is the EU's climate policy. It is not entirely consistent with Polish interests, and therefore Poland's activity in this field is rather defensive. The arrangements to which Poland consented in March 2007 concerning the EU's climate and energy goals (the 20-20-20 package, also known as the 3 x 20\% package or the Triple Twenties) are yet another problem. It took too long for Poland to become truly aware of their consequences for its

\footnotetext{
${ }^{28}$ Kowalewski, I., Mehlhausen, T. and Sus, M.: Poland's EU-Council Presidency under Evaluation: Navigating Europe though Stormy Waters, December 2013, at www.researchgate.net/publication, p. 23.

${ }^{29}$ Ministry of Foreign Affairs (2014): Poland's 10 years in ...op. cit., p. 53.

30 Madej, M.:"Wpływ udziału we Wspólnej Polityce Bezpieczeństwa i Obrony na polską politykę bezpieczeństwa" (Influence of the Participation in the Common Security and Defence Policy on Polish Security Policy), in Tereszkiewicz, F. (ed.) (2013): Polska w Unii Europejskiej. Bilans dekady, Warszawa, p. 261.
} 
economic growth and finance, given that the share of coal in the production of electricity in Poland is around 84 per cent. The fact that Poland became aware of this too late is the reason for its current defensive activity towards the climate and energy policy. Although Polish interests in this respect diverged from those of the EU's key actors, Poland managed to take advantage of the economic crisis in attempting to redefine the Union's climate policy. Quite often other voices in the EU also raised the issue that reducing $\mathrm{CO}_{2}$ emissions and the Emission Trading Scheme contributed to a reduced competitiveness of the European industry, while the major 'polluters' - the United States and China - were rather reluctant to reduce their own $\mathrm{CO}_{2}$ emissions. Poland's efforts will perhaps draw more attention in debates on energy and climate in the EU to the need of maintaining competitiveness of the Member States' economies, raising the importance of industry as well as economic and resource diversification of the Member States.

\section{Social aspects of Poland's Membership of the EU}

The balance of social gains and losses resulting from Poland's membership in the EU is hard to establish because it will be different for the state as a whole and for individual citizens. Whether the social consequences of EU membership for them are overall positive or negative is mainly determined by their livings standards. The most important social effect of Poland's accession to the EU, unquestioned, is that Poles have taken advantage of the opportunities brought by open borders and the free movement of people. According to Poles themselves, this is also one of the key benefits of accession (31\% of respondents), closely followed by the availability of EU structural funds (30\% of respondents). The most important consequence of open borders, in turn, is in their opinion the ability to seek employment and conduct business in the EU $(17 \%$ of respondents compared to $11 \%$ opting for investments in infrastructure as the key benefit from EU funds). ${ }^{31}$ A vast majority of the 'old' Member States established a transitional period that restricted the Poles' free access to the EU labour market. Only the United Kingdom, Ireland and Sweden decided to open their markets right on 1 May 2004. The other countries opened their markets in:

- 2006 - Finland, Portugal, Spain, Italy, and Greece

- 2007 - The Netherlands, Luxembourg

- 2008 - France

- 2009 - Belgium, Denmark

- 2011 - Germany, Austria

As the free movement of workers has been extended also to the countries of the European Economic Area (EEA), Poles could start seeking employment in Norway, Iceland and Lichtenstein as well. Switzerland, which is not an EEA member, is tied to the EU through a series of bilateral agreements that essentially extend the EEA's rules onto Switzerland as well. The country opened itself up to the Poles in 2011, but in May 2012 it introduced restrictions in the number of people employed, which it abolished again on 1 May 2014.

Poles took advantage of the new opportunities provided by the right to work in other EU countries in a higher proportion than had been expected. It is impossible to present accurate

\footnotetext{
3110 lat czlonkostwa Polski w Unii Europejskiej (10 Years of Poland's Membership in the European Union), conclusions from a CBOS survey, Warszawa, no. 52/14 (April 2014), p. 13.
} 
data on Polish migration after accession to the EU because of the differences between the methodologies applied in migration studies, between the individual Member States' population record systems and, finally, due to the very fact that migrations are fluid, that people can leave a country with the intent to stay abroad but after some time decide to come back. Moreover, statistical figures often do not take into account seasonal migration. Nonetheless, using data from various sources we can at least estimate the scale of the phenomenon. According to the Polish Central Statistical Office (GUS), the number of Poles temporarily staying abroad ${ }^{32}$ who migrated from Poland to other EU countries between 2004 and 2013 increased from 750,000 to 1.8 million. ${ }^{33}$ The largest wave of migration took place between 2004 and 2008, when the number of migrants increased by almost 150 per cent. Without quoting the remaining available data, let us assume that Poles working in other EU countries constitute some 5 per cent of the Polish society. Poles seem to prefer the United Kingdom, Germany, Ireland, the Netherlands, Italy, France and Norway as their destinations.

Table 5. The Most Popular Destinations for Polish Migrants in the EU

\begin{tabular}{|c|c|c|}
\hline Country & $\begin{array}{c}\text { Number of migrants at } \\
\text { the end of 2004 }\end{array}$ & $\begin{array}{c}\text { Number of migrants at } \\
\text { the end of 2014 }\end{array}$ \\
\hline The United Kingdom & 150 & 642 \\
\hline Germany & 383 & 115 \\
\hline Ireland & 15 & 113 \\
\hline The Netherlands & 23 & 96 \\
\hline Italy & 59 & 63 \\
\hline France & 30 & 71 \\
\hline Norway & no data & 49 \\
\hline Belgium & 13 & 40 \\
\hline Sweden & 11 & 960 \\
\hline
\end{tabular}

Source: Own compilation based on Table 1 in: Szacunek emigracji z Polski na pobyt czasowy w latach 2004-201, op. cit., p.3

Finally, Poles are also among the leading EU countries in terms of the number of its citizens living in another Member State; it holds the second place in this regard, after Romania, and is followed by Italy, Germany and the United Kingdom. ${ }^{34}$

\footnotetext{
${ }^{32}$ People who kept their permanent registered address in Poland although they reside abroad.

${ }^{33}$ Based on Table 1 in "Szacunek emigracji z Polski na pobyt czasowy w latach 2004-2013" (Estimations of Permanent and Temporary Emigration from Poland in 2004-2013), in Informacja o rozmiarach i kierunkach czasowej emigracji z Polski w latach 2004-2013 (Information on the Size and Directions of Temporary Emigration from Poland in 2004-2013), Central Statistical Office (GUS), Warszawa (October 2014), p. 3.

${ }^{34}$ C. Varga-Silva: EU Migrants in other EU Countries: An Analysis of Bilateral Migrant Stocks, Briefing, University of Oxford, www.migrationobservatory.ox.ac.uk., p. 5.
} 
The above data may indicate two regularities: first, Poles have no inhibitions and, after years of political isolation from Western Europe, now take fully the advantages and opportunities provided by the single market. Migrants include well educated people, who often speak two foreign languages, are highly qualified and fare very well abroad, establishing their own businesses or taking up employment at foreign companies; second, despite the achievements of the Polish economy since the transformation, Poland's economic situation is still not satisfactory enough to encourage people to remain in the country, especially when the labour markets of 31 other European countries (the EEA and Switzerland) are open to Poles. The main driving force behind labour migration are economic motives, low wages, lack of available jobs, or difficulties in finding a job. An analysis of data on wages and labour costs in EU countries shows that the decreasing difference in economic development between Poland and the EU was not followed by a decrease in the difference between the wages of Poles and citizens of other EU Member States. In 2013, the average annual net wage of a single childless person in Poland was EUR 7429 (EUR 619 monthly), which was lower only in five other EU countries (Latvia, Hungary, Lithuania, Romania, Bulgaria). Germans and the French earned three times more than Poles, while Danes and Brits earned four times more. Wages are highest in Norway (EUR 47,545) and Switzerland (EUR 59,357). ${ }^{35}$ The labour cost per hour in Poland in 2004-2014 rose from EUR 4.5 to 8.4 and is at present considerably lower than in, for example: Denmark (EUR 40), Belgium (EUR 39), the Netherlands (EUR 34), Germany (EUR 31), Ireland (EUR 29), or the United Kingdom (EUR 22); it is also much below the EU average of EUR 24.6 and the euro area average of EUR 29.2. ${ }^{36}$ The differences in wages will be lower if we take into account the price levels in those countries, but they are still, one of the key determinants of Polish migration, together with problems with finding a job.

The mobility of Polish workers contributed to the fall of unemployment in Poland, but with time the society started becoming increasingly aware of the threats related to the outflow of labour force, especially regarding the loss of qualified workers, young workers and women, who are more willing to have children abroad. ${ }^{37}$ Given the problem of population ageing, this could become a serious burden for Polish public finance; and the situation is additionally exacerbated by non-measurable social costs related to the phenomenon of 'Euro-orphans' and breakdown of marriages.

Poland's fast economic growth and the Polish migration contributed to a decrease in the disparities between the earnings of Poles measured according to the Gini coefficient since the accession. During the decade of membership, in terms of socio-economic equality Poland came closer to the EU average of 30.5 (for the EU-28). The coefficient in Poland decreased from 35.6 in 2005 to 30.7 in $2013 .^{38}$ Despite concerns that had been voiced before the accession, the level of poverty has not raised either. On the contrary, there have been positive changes in this area: in 2005, as much as 45 per cent of the society was at risk of poverty or social exclusion, while in 2013 it was 25.8 per cent and currently it is only slightly above the EU average of 24.5 per cent. ${ }^{39}$

\footnotetext{
${ }^{35}$ Data from www.forbes.pl.

${ }^{36}$ Eurostat: Labour costs per hour, 2004-2014, whole economy excluding agriculture and public administration,, data of 16.04.2014, www.ec.europa.eu/eurostat.

${ }^{37}$ In 2012, Polish women in the United Kingdom gave birth to the highest number of children among immigrant groups (21,156 births reported)."The Polish Paradox", The Economist, 14 December 2013, at www.economist.com.

${ }^{38}$ Eurostat: Gini coefficient of equalised disposable income, data of 02.03.2015 r., at www.ec.europa.eu/eurostat.

39 Eurostat: People at risk of poverty or social exclusion by age and sex, data of 07.07.2015, www.ec.europa.eu/eurostat.
} 
The free crossing of borders and the Schengen area are also part of the social aspect of Poland's membership in the EU. The elimination of visas and passport control was especially important for Poland in the symbolical dimension, given that for years the majority of the Polish society had been virtually unable to obtain a passport. Poles were now able to feel as full EU citizens. Currently, seven years after accession to the Schengen area (21 December 2007), 'the elimination of border control' is the average Pole's first response to this question: 'What do you associate the EU with?' And the respondents consider a return to the situation existing before 2007 as inconceivable.

Finally, the assessment of the social aspects of membership ends with the opportunities that the EU has created in the field of science and education. Polish students and researchers benefit from EU and EEA education programmes, while Polish universities open up to foreign students and researchers. The most recognisable programme: Erasmus, has been expanding quicker than the EU. Since 2004, the number of Polish universities holding the Erasmus University Charter has almost doubled, rising from 187 to 324 at the end of $2012,{ }^{40}$ just as the number of Polish and foreign students and academics. Apart from gaining new professional experience and investments in education and training, participation in education programmes supports the elimination of stereotypes, learning about different cultures and a general rapprochement of societies and consequently states. The accession to the EU has also had a considerable influence on the educational structure of population in Poland. First by implementing the goals of the Lisbon Strategy and now of the Europa 2020 strategy, Poland managed to successfully promote higher education. In the decade between 2002 and 2012, the percentage of people with higher education increased from 10 to 25 per cent and is now slightly below the EU average of 29 per cent. It will rise even further in the near future due to the commitments resulting from the Europa 2020 strategy to increase the number of people aged 30-34 who have higher education to at least 40 per cent. In 2013, 32 per cent of Poles in this age group had higher education (secondary education : $34 \%$, basic vocational education: $25 \%$, junior high school or lower: $9 \%),{ }^{41}$ therefore there is still some room for reform.

\section{Conclusion}

The results of the analysis of Poland's gains and losses resulting from the accession to the European Union presented in this article are clearly positive. After 1989, Poland had no alternative to the European Union, but the process of integration into the EU proved by all means to be beneficial. Economists believe that if Poland had not joined the EU, today it would be at the same level as Ukraine, whose GDP in 1990 was slightly higher than Poland's. Today, Poland's GDP is three times higher than Ukraine's. ${ }^{42}$ The decade of EU membership was a time of increased economic growth and modernisation in virtually every sphere: legal, institutional, economic, political, social. We are catching up with the EU, currently reaching $2 / 3$ of the average EU income and having started from $1 / 3$. The structural funds have changed, among others: the Polish road infrastructure, agriculture, industry, the environment, as well as culture infrastructure. The balance of gains and losses resulting from EU membership in the Polish sector of food and agricultural products, which was most anxious about the possible negative impact of accession, is clearly positive as well, despite the fact that some provisions

\footnotetext{
${ }^{40}$ www.erasmus.org.pl

41 Data from: Czarnik, Sz. Turek, K. (2014): Aktywność zawodowa i wyksztatcenie Polaków (Professional Activity and Education of Poles), Polish Agency for Enterprise Development, Warszawa, p. 62, at www.bkl.parp.gov.pl.

${ }^{42}$ Dekadę po wejściu do UE jesteśmy dwa razy bogatsi (A Decade after Accession We Are Two Times Richer), 30.04.2014, www.wyborcza.pl.
} 
of the Common Agricultural Policy could have negative consequences for producers (e.g., production and fishing quotas).

Poland's accession to the European Union and the Schengen space had a considerable influence on the country's standing in the international political arena. It consolidated Poland's security, sovereignty and significance in international relations. As a new EU Member State, Poland has not weakened the EU; on the contrary, perhaps its actions even prevented a division of the EU and clearly contributed to maintaining EU-wide unity. Poland came to be known as a country that understands the European compromises but also one that can pursue its interests in accordance with the interests of the EU as a whole. This was confirmed by the President of the European Parliament Martin Schulz who stated that within the ten years of its membership in the European Union, Poland had achieved an impressive development; Poland's position has weight and relevance in the European Union, and Poland sets important elements for the further development and integration of the community; Polish MEPs bring a valuable contribution to the works of the Parliament, never losing sight of the common European interest; Poland has found its role in the European Union. He further concluded that this change pleased him in particular as a German president of an international parliament. $^{43}$

This explicitly positive assessment of gains and losses from Poland's membership in the EU is also confirmed by polls and surveys, which showed that in March 2014 the support for EU membership among the Polish society was 89 per cent (with 7 per cent against and 4 per cent undecided). As regards the outcome of Poland's membership in the EU, 62 per cent of respondents consider it positive, 13 per cent negative and 20 per cent believe that the positive and negative effects were balanced out. ${ }^{44}$ What is interesting, however, is that Polish respondents found it difficult to name the negative consequences of the EU membership and that almost half of the respondents were unable to list them.

Indeed, it is difficult to name them, but this does not mean that after ten years of EU membership Poles have grown complacent. Despite the growing GDP and decreasing disproportions in development levels, the living standard of the average Polish family is still far from Western European standards, and, in terms of wage gap, Poland is in one of the last places among the EU Member States. The large-scale migration of Poles to EU and EEA countries can be discussed in terms of negative demographic and economic consequences as well as in terms of positive effects of the membership that contributed to the decreasing unemployment in Poland.

Poles may feel some dissatisfaction in political terms, however. The government failed to maintain the EU's engagement in one aspect of foreign policy that is of key importance to Poland: the conflict in Ukraine. What is more, strategic talks on Ukraine (Poland considers itself Ukraine's advocate in the EU), i.e. on the Minsk agreement of February 2015, took place without representatives of Poland but instead with the presence of the leaders of Germany, France, Russia, and Ukraine. After ten years of membership, Poland is not part of the strict core of EU decision-making, but it has still managed to remain in the mainstream, mainly through the use of community mechanisms in the decision-making process. Poland aspires to be perceived as one of the leaders having the greatest impact on the decisions made in the EU; it is only a shame that Polish decision-makers identify this advance with joining the euro area.

\footnotetext{
${ }^{43}$ Schulz, Martin (2014): Skrepowany OLBRZYM. Ostatnia szansa Europy (A Tied-Up Giant. Europe's Last Chance), MUZA SA, Warszawa, p. 12 after: Fiszer, Józef: Dziesięć lat członkostwa Polski w Unii Europejskiej. Próba bilansu (Ten Years of Poland's Membership of the EU. Towards an Assessment), at www.kongreseuropeistyki.uw.edu.pl/aktualnosci.

${ }^{44} 10$ lat członkostwa Polski w Unii Europejskiej..., op. cit., pp. 4-5.
} 
The main future challenge will be to maintain the present good trends in the economy. The coming decade could be more difficult than the previous one because the competitiveness of the Polish economy cannot be maintained relying on low labour costs. The Polish economic policy and the reforms that fuel it need to take into account the increasing importance of innovation because at present Poland ranks very low in international rankings of innovation. This will require reforms in the labour market, in research and development, taxes, the functioning of enterprises, education, as well as discipline on the Polish political stage. Drawing more benefits from the EU membership will also become more difficult because of the crisis that endures in the euro area as well as new threats to the EU's stability and security. The inflow of illegal immigrants, the threat of terrorism and the conflict in Ukraine are just some of many variables in the international environment to which Poland needs to skilfully react. 